\title{
Uji Efektivitas Bioherbisida Ekstrak Etil Asetat Babadotan (Ageratum conyzoides L.) dari Berbagai Ketinggian Tempat Dan Konsentrasi terhadap Pertumbuhaan Gulma Bayam Duri (Amaranthus spinosus L.)
}

\author{
The Test of Effectiveness Whiteweed Ethyl Acetate Extract \\ (Ageratum conyzoides L.) from Various Altitudes And Concentration \\ Against the Growth of Spiny Amaranth Weed (Amaranthus spinosus L.) \\ Zainuddin $^{1}$, Siti Hafsah ${ }^{1}$, Gina Erida ${ }^{*}$ \\ Program Studi Agroteknologi, Fakultas Pertanian, Universitas Syiah Kuala
}

\begin{abstract}
Abstrak. Penelitian ini bertujuan untuk menguji aktivitas ekstrak etil asetat babadotan dari berbagai ketinggian tempat dan konsentrasi terhadap pertumbuhan gulma bayam duri. Penelitian ini dilaksanakan di Laboratorium Ilmu Gulma Program Studi Agroteknologi dan Kebun Percobaan Fakultas Pertanian Universitas Syiah Kuala Banda Aceh, serta Laboratorium Analisis Kimia Fakultas Matematika dan Ilmu Pengetahuan Alam (FMIPA), sejak September 2017- Januari 2018. Bahan yang digunakan adalah benih bayam duri, yang diperoleh dari Kecamatan Delima Kabupaten Pidie dan daun babadotan yang diperoleh dari 3 daerah dengan ketinggian yang berbeda yaitu Kecamatan Indrapuri Kabupaten Aceh Besar (19 mdpl), Kecamatan Lembah Seulawah Saree Kabupaten Aceh Besar (261 mdpl) dan Kecamatan Takengon Kabupaten Aceh Tengah (1259 mdpl) dengan konsentrasi 5, 10 dan 15\% sebagai bioherbisida. Rancangan yang digunakan dalam penelitian ini adalah Rancangan Acak Lengkap (RAL) pola faktorial $3 \times 3$ dengan 3 kali ulangan. Faktor pertama yaitu ketinggian tempat dengan 3 taraf dan faktor kedua konsentrasi dengan 3 taraf. Ekstrak yang dihasilkan pada ketinggian tempat yang berbeda dan konsentrasi ekstrak etil asetat berpengaruh nyata terhadap laju tinggi, jumlah daun, diameter batang, persentase pengendalian dan panjang akar. Terdapat interaksi antara ketinggian tempat dan konsentrasi terhadap persentase pengendalian pada 7 dan 14 HSA. Ekstrak yang dihasilkan pada ketinggian 9 mdpl dengan konsentrasi 10\% dapat mengendalikan gulma bayam duri hingga 100\% pada 7 HSA.
\end{abstract}

Kata kunci: bioherbisida, bayam duri, babadotan, pertumbuhan dan ketinggian tempat.

\begin{abstract}
This study aims to examine the activity of ethyl acetate fraction of whiteweed extract from various altitudes and concentration againts the growth of spiny amaranth. This research was conducted at Laboratory of Weed Science, Agrotechnology Department, and Experimental Garden, Agriculture Faculty, Syiah Kuala University Banda Aceh, and Laboratory of Chemical Analysis Mathematics Faculty and Natural Science, from September 2017 to January 2018. The materials used is spiny amaranth seed that obtained from Subdistrict of Delima, District of Pidie and babadotan leaves obtained from three regions with different altitude that is Subdistrict of Indrapuri, District of Aceh Besar (19 masl), Subdistrict of Subdistrict of, District of Aceh Besar (261 masl) and Subdistrict of Takengon District of Aceh Tengah (1259 masl) with each concentration 5, 10 and $15 \%$ as bioherbicide. This research using Randomized Completely Design with Factorial pattern which has $3 \times 3$ treatments and 3 replication. The first faktor is altitude and second is concentration of ethyl acetate extract. Ethyl acetate extracts that produced in different altitudes and concentrations were significantly influence the high rate of spiny amaranth, number of leaves, stem diameter, control percentage and root length. There is an interaction between altitude and concentration on the percentage of control at 7 and 14 HSA. Extracts produced at an altitude of 9 masl with a concentration of $10 \%$ can control spinach weeds up to $100 \%$ at 7 HSA.
\end{abstract}

Keywords: bioherbicide, spiny amaranth, whiteweed, growth and altitude

\section{PENDAHULUAN}

Brown dan Brooks (2002) menyatakan gulma ialah tumbuhan yang ada pada suatu areal tanaman yang mengganggu tanaman utama dan tidak dikehendaki keberadaannya. Kehadiran gulma di antara tanaman budidaya dapat menyebabkan persaingan dalam memperebutkan unsur hara, air, cahaya dan ruang tumbuh. Pengendalian gulma merupakan suatu usaha untuk mengubah keseimbangan ekologis yang bertujuan untuk menekan 
pertumbuhan gulma, tetapi tidak berpengaruh negatif terhadap tanaman budidaya (Sukman dan Yakup, 2002). Pengendalian gulma dapat dilakukan dengan berbagai cara, salah satunya dengan bahan kimia (herbisida). Penggunaan herbisida sintetik dapat menimbulkan berbagai masalah, yaitu biaya penyediaan herbisida yang mahal, pencemaran lingkungan, penurunan kadar organik tanah, dan gulma menjadi toleran terhadap jenis herbisida tertentu (Duke et al.,1993). Oleh sebab itu diperlukan alternatif pengendalian gulma yang ramah lingkungan, serta tidak menimbulkan residu pada produk pertanian. Pengendalian tersebut dapat dilakukan dengan mencari potensi metabolit sekunder (alelokimia) yang berasal dari tumbuhan lain sehingga dapat dimanfaatkan sebagai bioherbisida. (Riskitavani dan Kristanti, 2013).

Babadotan (Ageratum conyzoides L.) merupakan salah satu gulma yang dapat berpotensi sebagai bioherbisida karena mempunyai senyawa alelopat. Potensi ini dapat dilihat dari indikasi dominannya babadotan dibandingkan gulma lain dalam suatu lahan (Sukamto, 2007). Babadotan mengandung alelokimia yang mampu menghambat pertumbuhan diantaranya flavonoid, chromene, benzofuran, dan terpenoid dengan melepaskan senyawa volatil ke lingkungan (Kong, 2006).

Fazira (2017), menyatakan bahwa pemberian ekstrak metanol babadotan mampu menekan persentase pengendalian gulma pada dosis 20\%. Lisnawati (2017), menyatakan bahwa pemberian bioherbisida esktrak n-heksan daun babadotan pada dosis $15 \%$ mampu mengendalikan gulma bayam duri sebesar 74,05\%. Penelitian Hidayat (2017) menunjukkan bahwa penggunaan ekstrak babadotan dengan pelarut etil asetat dengan dosis $15 \%$ mampu mengendalikan bayam duri sebesar $86,2 \%$.

Menurut Putri et al. (2013), bahwa etil asetat merupakan salah satu pelarut yang memiliki sifat semi polar dengan toksisitas yang rendah dan diharapkan mampu menarik senyawa yang bersifat polar dan non polar. Pranoto et al. (2012) menambahkan bahwa etil asetat adalah jenis pelarut yang memiliki karakteristik sebagai pelarut semi polar. Secara selektif pelarut etil asetat akan menarik senyawa-senyawa yang bersifat semi polar seperti fenol dan terpenoid.

Efektifitas suatu bioherbisida dapat ditunjukkan pada respon gulma indikator, salah satu gulma indikator yang digunakan adalah bayam duri. Menurut Mohamad (2012) bayam duri merupakan tumbuhan liar, yang mudah didapat dan tersedia dalam jumlah yang banyak, pertumbuhannya cepat serta terdapat di mana mana. Bayam duri dapat digunakan sebagai gulma indikator dalam penelitian alelopati, hal ini dkarenakan tingkat perkecambahan yang tinggi dan mudah perbanyakannya. Perkecambahan bayam duri pada permukaan tanah dapat mencapai 56\% dan apabila dikecambahkan pada germinator dengan suhu $68^{\circ}$ dapat mencapai hingga 78\% (Nice et al. 2011 dalam Tarigan, 2015).

Menurut Lakitan (2002), variasi suhu di indonesia tergantung pada ketinggian tempat, suhu udara akan semakin rendah seiring dengan semakin tingginya tempat dari permukaan laut. Suhu menurun sekitar $0,6^{0} \mathrm{C}$ setiap $100 \mathrm{~m}$ kenaikan ketinggian tempat dari permukaan laut. Diantara faktor iklim, suhu merupakan salah satu faktor yang mempunyai peranan utama dalam proses pertumbuhan karena suhu dapat pula mempengaruhi aktifitas metabolisme tanaman. Pengaruhnya terutama pada proses yang menyangkut reaksi thermokimia. Penelitian Rahma (2013) menyatakan bahwa tanaman rimpang (Kaempferia parviflora) pada ketinggian 1.200 mdpl memiliki kandungan bahan aktif yang lebih tinggi daripada rimpang pada ketinggian $240 \mathrm{mdpl}$. Kandungan alkaloid, steroid dan glikosida pada rimpang di ketinggian 1.200 mdpl dinyatakan lebih positif dibandingkan pada ketinggian 240 mdpl. Penelitian ini bertujuan untuk mengetahui pengaruh etil asetat ekstrak babadotan dari berbagai ketinggian tempat dan konsentrasi terhadap pertumbuhan bayam duri. 


\section{METODE PENELITIAN}

Penelitian ini dilaksanakan di Laboratorium Ilmu Gulma Program Studi Agroteknologi Fakultas Pertanian, Laboratorium Analisis Kimia Fakultas Matematika dan Ilmu Pengetahuan Alam (FMIPA), dan Kebun Percobaan Fakultas Pertanian Universitas Syiah Kuala Banda Aceh.

\section{MATERI DAN METODE}

\section{Bahan dan Alat Penelitian}

Bahan yang digunakan dalam penelitian ini adalah benih bayam duri, yang diperoleh dari Kecamatan Delima Kabupaten Pidie, daun babadotan yang diperoleh dari Kecamatan Indrapuri Kabupaten Aceh Besar, Kecamatan Lembah Seulawah Saree Kabupaten Aceh Besar, Kecamatan Takengon Kabupaten Aceh Tengah, aquades, herbisida 2,4 D, ammonia 70\%, pelarut n-heksane dan etil asetat, kertas label, kapas, pasir, air RO (Reverse Osmosis), pupuk kandang dan tanah topsoil yang diperoleh dari Kecamatan Indrapuri Kabupaten Aceh Besar, lesung, wadah kaleng, saringan, kapas, karung goni, corong, aluminium foil, penggaris, jangka sorong, Rotary evaporator, timbangan analitik, ayakan pasir 12 mesh, pot volume $1 \mathrm{~kg}$, sprayer, tempat penampung air, sprayer, dan oven.

\section{Metode Penelitian}

Rancangan yang digunakan dalam penelitian ini adalah Rancangan Acak Lengkap (RAL) pola faktorial $3 \times 3$ dengan 3 kali ulangan. Faktor pertama yaitu ketinggian tempat dengan 3 taraf dan faktor kedua konsentrasi dengan 3 taraf sehingga terdapat 27 satuan percobaan. Setiap satuan percobaan terdiri dari 4 unit gulma, sehingga terdapat 108 unit .

\section{Pelaksanaan Penelitian \\ Persiapan Sampel}

Sampel daun babadotan diambil dari Kecamatan Indrapuri Kabupaten Aceh Besar, Saree Kabupaten Aceh Besar dan Takengon Kabupaten Aceh Tengah. Adapun daun yang diambil adalah yang pertumbuhannya optimum yaitu secara fisik segar dan bentuk daun sempurna.

\section{Pembuatan Ekstrak}

Daun babadotan dibersihkan dari kotoran dan dikeringanginkan selama \pm 10 hari. Daun yang sudah kering dihaluskan dengan menggunakan lesung kayu, dibasakan dengan ammonia 70\% selama lebih kurang 1 jam, sampel di maserasi selama 3x24 jam dengan pelarut n-heksane lalu disaring dengan menggunakan kapas kemudian dimaserasi ulang dengan n-heksane selama 3×24 jam sampai diperoleh senyawa yang terekstrak sempurna dengan pelarut $n$-heksane. Residu dikeringanginkan selama lebih kurang 1 jam. Residu Nheksan dimaserasi dengan pelarut etil asetat selama 3x24 jam dan dilakukan sebanyak dua kali. Setelah itu dilakukan penyaringan dengan menggunakan kapas untuk memisahkan filtrat dari ampasnya. Filtrat yang dihasilkan kemudian diuapkan dengan Rotary evaporator pada suhu $40^{\circ} \mathrm{C}$, kemudian dihasilkan ekstrak pekat babadotan. Langkah-langkah pembuatan ekstrak dapat dilihat pada lampiran 2.

\section{Uji Fitokimia}

Analisis uji fitokimia dilakukan di Laboratorium Analisis Kimia Fakultas Matematika dan Ilmu Pengetahuan Alam (FMIPA) Universitas Syiah Kuala. Pengujian ini dilakukan agar diketahui senyawa kimia apa saja yang terkandung pada fraksi etil asetat ekstrak babadotan. 
Cara yang dilakukan untuk melakukan uji fitokimia adalah analisis fitokimia dengan penampakan noda. Penampakan noda masing-masing senyawa berbeda-beda. Pada pengujian ini dilakukan beberapa metode, adapun metodenya sebagai berikut :

\section{Uji Fitokimia Alkaloid}

Sampel tanaman yang meliputi bagian akar, kulit batang, buah dan biji digerus kemudian dibasakan dengan amoniak. Selanjutnya ditambahkan $10 \mathrm{ml}$ kloroform kemudian digerus dan disaring. Filtrat yang dihasilkan ditambah asam klorida 5\% sebanyak $10 \mathrm{ml}$, dikocok kuat-kuat, didiamkan sampai larutan asam klorida dan kloroform memisah. Selanjutnya lapisan asam klorida yang berada diatas diambil dan dibagi dalam tiga tabung, dimana masing-masing tabung di uji dengan menggunakan reagen Dragendorff, reagen Meyer dan reagen Wagner untuk mengetahui keberadaan alkaoid.

Penambahan reagen Dragendorff akan menghasilakan endapan kemerahan. Penambahan reagen Meyer akan menghasilkan endapan putih dan penambahan reagen Wagner menghasilkan endapan coklat sehingga positif adanya alkaloid. Langkah-langkah uji fitokimia senyawa alkaloid dapat dilihat pada lampiran 3 .

\section{Uji Fitokimia Terpenoid, Steroid dan Saponin}

Sampel sebanyak $10 \mathrm{~g}$ dihaluskan selanjutnya diekstraksi dengan etil asetat dan disaring. Filtrat yang diperoleh dipekatkan dengan rotary evaporator sehingga didapatkan ekstrak etil asetat. Fraksi yang larut dalam etil asetat di uji dengan reagen LibermannBuorchard. Bila warnanya hijau atau biru maka positif adanya steroid. Bila warnanya merah maka positif adanya terpenoid. Bila warnanya merah atau ungu maka positif adanya triterpenoid.

Fraksi yang tidak larut dalam etil asetat ditambahkan sedikit air dan dikocok kuat-kuat jika terbentuk busa yang stabil selama 30 menit maka positif adanya saponin. Selanjutnya larutan saponin tersebut di hidrolisis dengan $\mathrm{HCl}$, kemudian di uji dengan pereaksi Libermann-Buorchard. Bila larutan bewarna hijau atau biru maka positif adanya saponin steroid. Bila larutan bewarna merah atau ungu maka positif adanya saponin triterpenoid. Langkah-langkah uji fitokimia senyawa terpenoid, steroid dan saponin dapat dilihat pada skema lampiran 4.

\section{Uji Fitokimia Flavonoid}

Pada uji flavonoid, ekstrak dari setiap sampel ditambahkan etil asetat dan dikocok dengan kuat. Kemudian residu diektraksi dengan $10 \mathrm{ml}$ etanol $80 \%$, selanjutnya ditambah 0,5 mg logam magnesium dan $\mathrm{HCl} 0,5 \mathrm{M}$. Jika larutan warna merah muda atau ungu menunjukkan ada flavonoid. Langkah-langkah uji fitokimia senyawa flavonoid dapat dilihat pada skema lampiran 5.

\section{Persiapan Media Tumbuh}

Tanah yang digunakan adalah tanah lapisan topsoil yang diambil dengan kedalaman $20 \mathrm{~cm}$, diperoleh dari Kecamatan Indrapuri Kabupaten Aceh Besar. Tanah yang diambil dikeringanginkan selama 3 hari, dipisahkan dari sisa-sisa tanaman dan diayak. Tanah tersebut dicampur dengan pupuk kandang dengan perbandingan 1:1 kemudian tanah tersebut dimasukkan ke dalam pot dengan volume $1 \mathrm{~kg}$.

\section{Penanaman Benih Bayam Duri}

Setelah tanah dimasukkan kedalam pot, benih bayam duri ditanam sebanyak 5 benih per pot dan setelah berumur 1 minggu dipilih 1 yang pertumbuhannya terbaik sebagai gulma indikator sedangkan yang lain dicabut.

\section{Penyiraman}

Penyiraman dilakukan setiap pagi dan sore hari dengan menggunakan air RO (Reverse Osmosis) dengan jumlah yang sama dan pada waktu yang sama. 


\section{Aplikasi Ekstrak Tumbuhan}

Etil asetat ekstrak babadotan diberikan pada setiap unit percobaan kecuali kontrol sebanyak 1 kali yaitu pada saat daun bayam duri sudah berkembang sempurna namun tanaman belum berbunga. Aplikasi dilakukan dengan cara menyemprot cairan fraksi etil asetat dengan menggunakan hand sprayer keseluruh bagian tanaman bayam duri. Kebutuhan larutan per pot kurang lebih $8 \mathrm{ml}$ sehingga dalam 12 pot dibutuhkan $96 \mathrm{ml}$ larutan. Adapun kebutuhan ekstrak per perlakuan adalah sebagai berikut:

Konsentrasi $5 \%=5 / 100 \times 96=4,8 \mathrm{ml}$

Konsentrasi $10 \%=10 / 100 \times 96=9,6 \mathrm{ml}$

Konsentrasi $15 \%=15 / 100 \times 96=14,4 \mathrm{ml}$

\section{Parameter Pengamatan}

Parameter yang diamati adalah laju tinggi gulma, jumlah daun, diameter batang, persentase pengendalian, panjang akar, bobot kering akar dan bobot kering tajuk.

\section{HASIL DAN PEMBAHASAN}

\section{Uji Fitokimia}

Hasil uji fitokimia dari ekstak etil asetat babadotan yang di ambil dari Indrapuri (19 mdpl), Saree (261 mdpl) dan Takengon (1259 mdpl) dapat dilihat pada Tabel 2

Tabel 1. Hasil uji fitokimia etil asetat ekstrak babadotan Indrapuri (19 mdpl), Saree (261 mdpl) dan Takengon (1259 mdpl).

\begin{tabular}{|c|c|c|c|}
\hline \multicolumn{4}{|c|}{ Indrapuri (19 mdpl) Saree (261 mdpl) dan Takengon (1259 mdpl). } \\
\hline No & Senyawa & Warna jika hasilnya positif & Hasil \\
\hline 1 & $\begin{array}{l}\text { Alkaloid } \\
\qquad \begin{array}{l}\text { - Meyer } \\
\text { - Dragendorff } \\
\text { - Wagner }\end{array}\end{array}$ & $\begin{array}{l}\text { - endapan putih } \\
\text { - endapan kemerahan } \\
\text { - endapan coklat }\end{array}$ & $\begin{array}{l}- \\
- \\
-\end{array}$ \\
\hline 2 & Terpenoid & Merah & - \\
\hline 3 & Steroid & hijau atau biru & + \\
\hline 4 & Saponin & terbentuk busa & - \\
\hline 5 & Flavonoid & merah muda atau ungu & - \\
\hline 6 & Tanin & warna hijau kebiruan & + \\
\hline
\end{tabular}

Berdasarkan hasil uji fitokimia terhadap ekstrak yang berasal dari lokasi berbeda tersebut menunjukkan bahwa pada ekstrak yang berasal dari ketiga lokasi yang berbeda ketinggian tersebut diketahui mengandung senyawa steroid dan tanin, hal ini karena terbentuk endapat berwarna biru. Pada ekstrak tersebut tidak mengandung alkaloid, terpenoid, saponin dan flavonoid.

\section{Laju Tinggi Gulma}

Hasil penelitian menunjukkan bahwa perlakuan ekstrak etil asetat babadotan dari berbagai ketinggian dan kosentrasi berpengaruh terhadap laju tinggi gulma bayam duri pada 
7-14, 14-21, dan 21-28 HSA serta tidak ada interaksi antara ketinggian dan dosis ekstrak etil asetat babadotan. Rerata hasil pengamatan laju tinggi gulma bayam duri dapat di lihat pada Tabel 2.

Tabel 2. Rerata laju tinggi gulma bayam duri akibat pemberian ekstrak etil asetat babadotan dari berbagai ketinggian pada berbagai konsentrasi

$$
\text { Rerata laju tinggi gulma }(\mathrm{cm})
$$

Perlakuan
7-14 HSA
14-21 HSA
21-28 HSA

Ketinggian (mdpl)

19

$0,09 \mathrm{a}^{*}$

$0,12 \mathrm{a}$

0,40

261

$0.21 \mathrm{~b}$

$0,08 \mathrm{a}$

0,58

1259

$0,29 \mathrm{~b}$

$0,39 \mathrm{~b}$

0,81

\section{Konsentrasi (\%)}

$\begin{array}{llll}5 & 1,44 \mathrm{~b} & 0,92 \mathrm{~b} & 1,17 \mathrm{~b} \\ 10 & 0,26 \mathrm{a} & 0,66 \mathrm{ab} & 0,50 \mathrm{a} \\ 15 & 0,06 \mathrm{a} & 0,20 \mathrm{a} & 0,12 \mathrm{a}\end{array}$

Keterangan: - Angka-angka yang diikuti oleh huruf dan kolom yang sama menunjukkan tidak berbeda nyata pada uji DNMRT $(\alpha=0,05)$

- Transformasi data menggunakan $\sqrt{ } \mathrm{x}+0,5$.

Tabel 2 menunjukkan bahwa ekstrak etil asetat babadotan yang dihasilkan pada ketinggian 19 mdpl pada 7-14 HSA dapat menurunkan laju tinggi bayam duri lebih baik dibandingkan dengan ekstrak etil asetat babadotan yang dihasilkan pada ketinggian $261 \mathrm{mdpl}$ dan 1259 mdpl. Rice (1979) menyatakan bahwa produksi senyawa alelopati dapat dipengaruhi oleh beberapa faktor linkungan diantaranya yaitu intensitas cahaya, kekurangan unsur hara, lingkungan yang kekeringan dan suhu lingkungan yang tidak sesuai dengan suhu normal bagi pertumbuhan. Alelopati merupakan salah satu senyawa metabolik sekunder yang dihasilkan oleh tumbuhan. Menurut Nurnasari (2010) ketinggian tempat berpengaruh terhadap metabolik sekunder nikotin yang dihasilkan oleh tembakau. Unsur lingkungan yang mempengaruhi kadar metabolik sekunder nikotin adalah temperatur udara dan kelembaban relatif.

Pemberian ekstrak etil asetat babadotan pada konsentrasi $10 \%$ dan $15 \%$ memiliki pengaruh yang lebih baik dalam menurunkan laju tinggi gulma bayam duri dibandingkan dengan konsentrasi 5\%. Hafsah et al. (2012) menyatakan bahwa pemberian cairan perasan Ageratum conyzoides dapat menekan pertumbuhan tanaman sawi pada pengamatan tinggi tanaman lebih baik seiring dengan peningkatan konsentrasi cairan perasan. Nisrina (2017) menyatakan bahwa pada ekstrak babadotan mengandung senyawa kumarin yang dapat menghambat pertumbuhan dan mengakibatkan tanaman tidak tumbuh dan berkembang secara normal.

\section{Persentase Pengendalian}

Hasil menunjukkan bahwa perlakuan ekstrak etil asetat babadotan dari berbagai ketinggian dan konsentrasi berpengaruh terhadap persentase pengendalian gulma bayam duri 
pada 21 dan 28 HSA serta terdapat interaksi antara ketinggian dan dosis ekstrak etil asetat babadotan pada 7 dan 14 HSA.

Tabel 3. Rerata persentase pengendalian gulma bayam duri akibat pemberian ekstrak etil asetat dari berbagai ketinggian pada berbagai konsentrasi

\begin{tabular}{|c|c|c|c|}
\hline \multirow{2}{*}{ Perlakuan } & \multicolumn{3}{|c|}{7 HSA } \\
\hline & $5 \%$ & $10 \%$ & $15 \%$ \\
\hline \multicolumn{4}{|c|}{ Ketinggian (mdpl) } \\
\hline 19 & $30,83 \mathrm{Ac}$ & $100,00 \mathrm{Bb}$ & $100,00 \mathrm{Ba}$ \\
\hline 261 & $17,50 \mathrm{Ab}$ & $95,00 \mathrm{Ba}$ & $100,00 \mathrm{Ba}$ \\
\hline 1259 & $5,83 \mathrm{Aa}$ & $97,08 \mathrm{Ba}$ & $97,50 \mathrm{Ba}$ \\
\hline \multirow{2}{*}{ Perlakuan } & \multicolumn{3}{|c|}{$14 \mathrm{HSA}$} \\
\hline & $5 \%$ & $10 \%$ & $15 \%$ \\
\hline \multicolumn{4}{|c|}{ Ketinggian (mdpl) } \\
\hline 19 & $18,89 \mathrm{Ab}$ & $100,00 \mathrm{Bb}$ & $100,00 \mathrm{Ba}$ \\
\hline 261 & $5,56 \mathrm{Ab}$ & $84,44 \mathrm{Ba}$ & $100,00 \mathrm{Ca}$ \\
\hline 1259 & $0,00 \mathrm{Aa}$ & $74,44 \mathrm{Ba}$ & $95,56 \mathrm{Ca}$ \\
\hline
\end{tabular}

Keterangan: Angka-angka yang diikuti oleh huruf yang sama (huruf besar vertikal huruf kecil horizontal) menunjukkan tidak berbeda nyata pada uji DNMRT $(\alpha=0,05)$

Tabel 4. Rerata persentase pengendalian gulma bayam duri akibat pemberian ekstrak etil asetat dari berbagai ketinggian pada berbagai konsentrasi

\begin{tabular}{lcc}
\hline \multirow{2}{*}{$\begin{array}{c}\text { Ketinggian(mdpl) } \\
\text { dan konsentrasi }\end{array}$} & Rerata persentase pengendalian gulma bayam duri (\%) \\
\cline { 2 - 3 } & $21 \mathrm{HSA}$ & $28 \mathrm{HSA}$ \\
\hline Ketinggian (mdpl) & & \\
19 & $70,56 \mathrm{~b}^{*}$ & 66,67 \\
261 & $58,89 \mathrm{a}$ & 56,67 \\
1259 & $51,11 \mathrm{a}$ & 38,89 \\
\hline Konsentrasi $(\%)$ & $6,11 \mathrm{a}$ & $1,11 \mathrm{a}$ \\
5 & $77,22 \mathrm{~b}$ & $67,78 \mathrm{~b}$ \\
10 & $97,22 \mathrm{c}$ & $93,33 \mathrm{~b}$ \\
\hline
\end{tabular}

Keterangan: - Angka-angka yang diikuti oleh huruf dan kolom yang sama menunjukkan tidak berbeda nyata pada uji DNMRT $(\alpha=0,05)$

- Transformasi data menggunakan Arcsin $\sqrt{ }$.

Tabel 3 dan 4 menunjukkan bahwa ketinggian dan konsentrasi ekstrak etil asetat babadotan berpengaruh terhadap persentase pengendalian. Semakin tinggi kosentrasi maka semakin tinggi juga persentase pengendalian gulma. Hal ini dapat di lihat pada perlakuan 19 mdpl $10 \%$ yang menunjukkan pengendalian hingga $100 \%$ pada 7 HSA. Ketinggian tempat yang berbeda mengakibatkan adanya perbedaan kondisi lingkungan yang meliputi intensitas 
cahaya matahari, suhu udara, kelembapan relatif, dan kecepatan angin (Unal et al., 2013). Babadotan dapat hidup di tempat yang tidak tergenang air pada daerah tropis dan subtropis dari ketinggian 1-1.200 mdpl. Suhu optimal untuk tumbuh babadotan antara $16{ }^{\circ} \mathrm{C}$ sampai dengan $24{ }^{\circ} \mathrm{C}$ (Moenandir, 1994 dalam Andi, 2007). Gaofeng et al. (2018) menyatakan bahwa Oryza longistaminata yang ditanam pada suhu $35^{\circ} \mathrm{C}$ dapat memberikan pengaruh alelopati yang lebih kuat terhadap sekitarnya dibandingkan dengan $O$. longistaminata pada suhu $25^{\circ} \mathrm{C}$ dan $15^{\circ} \mathrm{C}$.

Penelitian Julio (2017) menyatakan bahwa pemberian ekstrak babadotan dengan konsentrasi $10 \%$ pada 7 HSA memberikan pengaruh persentase pengendalian gulma $100 \%$ dan juga penelitian Farizah (2017) yang menyatakan bahwa aplikasi ekstrak babadotan dengan konsentrasi $20 \%$ dapat memberikan pengaruh persentase pengendalian sebesar $100 \%$.

\section{KESIMPULAN DAN SARAN}

Ekstrak etil asetat babadotan yang dihasilkan pada ketinggian tempat yang berbeda berpengaruh nyata terhadap laju tinggi dan persentase pengendalian. Pemberian ekstrak etil asetat babadotan dengan konsentrasi tinggi dapat menekan pertumbuhan gulma bayam duri lebih baik daripada konsentrasi rendah. Terdapat interaksi antara ketinggian tempat dan konsentrasi terhadap persentase pengendalian pada 7 dan 14 HSA. Ekstrak yang dihasilkan pada ketinggian 9 mdpl dengan konsentrasi $10 \%$ dapat mengendalikan gulma bayam duri hingga $100 \%$ pada 7 HSA.

\section{DAFTAR PUSTAKA}

Andi, S. 2007. Efikasi ekstrak babandotan (ageratum conyzoides 1.) terhadap crocidolomia binotalis zeller. Skripsi. Jurusan Perlindungan Tanaman Fakultas Pertanian Universitas Bengkulu.

Brown, K., dan K. Brooks.2002. Bushland Weeds: a Practical Guide to their Management, Environmental Weeds Action Network (WA) Inc. Perth WA.

Duke, S. O dan J. Lydon. 1993. Natural phytotoxins as herbisida. Pes control with enhadce environmental safety. ACS symp ser 542. Amer Chem Soc. 111-121.

Farizah. 2017. Potensi alelopati beberapa gulma sebagai bioherbisida terhadap pertumbuhan gulma bayam duri (Amaranthus spinosus L,). Skripsi. Jurusan Agroteknologi Fakultas Pertanian Universitas Syiah Kuala.

Fazira, I. 2017. Aktivitas bioherbisida ekstrak babadotan (Ageratum conyzoides L.) dengan pelarut etil asetat terhadap pertumbuhan gulma bayam duri (Amaranthus spinosus L.) Skripsi. Jurusan Agroteknologi Fakultas Pertanian Universitas Syiah Kuala.

Gaofeng, X., S. Shen, Z. Yun, Z. Hisashi, K.N David. 2018. Relationship between allelopathic effects and functional traits of different allelopathic potential rice accessions at different growth stages. J. Rice Science. 25: 32-41

Hafsah, S., M.A Ulim dan C,M. Noviyanti. 2012. Efek alelopatu Ageratum conyzoides L, terhadap pertumbuhan sawi. J. Floratek. 8: 18-24

Hidayat, T. 2017. Aktivitas bioherbisida ekstrak babadotan (Ageratum conyzoides L.) dengan pelarut etil asetat terhadap pertumbuhan gulma bayam duri (Amaranthus spinosus L.) Skripsi. Jurusan Agroteknologi Fakultas Pertanian Universitas Syiah Kuala. 
Julio, A. 2017. Uji Aktivitas fraksi etil asetat (Subfraksi A) ekstrak babadotan (Ageratum conyzoides L.) terhadap pertumbuhan gulma bayam duri (Amaranthus spinosus L.) Skripsi. Jurusan Agroteknologi Fakultas Pertanian Universitas Syiah Kuala.

Kong, C. 2006. Allelochemicals from Ageratum conyzoides L. and Oriza sativa L. and their effects on related pathogens. 194-195.

Lakitan. 2002. Klasifikasi Iklim Indonesia. PT, Dunia Pustaka Jaya: Jakarta.

Lisnawati. 2017. Aktifitas bioherbisida ekstrak N-heksan dari Ageratum conyzoides terhadap pertumbuhan gulma Amaranthus spinosus. Skripsi. Jurusan Agroteknologi Fakultas Pertanian Universitas Syiah Kuala.

Moenandir, J. 1998. Pengantar Ilmu dalam Pengedalian Gulma. Rajawali. Jakarta.

Mohamad. E. 2012. Fitoremediasi logam berat kadmium (Cd) pada tanah dengan penggunaan bayam duri (A. Spinosus). Laporan Penelitian Pengembangan IPTEK. Universitas Negeri Gorontalo.

Nisrina, L. 2017. Uji Aktivitas fraksi etil asetat (Subfraksi A) ekstrak babadotan (Ageratum conyzoides L.) terhadap pertumbuhan gulma bayam duri (Amaranthus spinosus L.) Skripsi. Jurusan Agroteknologi Fakultas Pertanian Universitas Syiah Kuala.

Nurnasari, E dan Djumali. 2010. Pengaruh kondisi ketinggian tempat terhadap produksi dan mutu tembakau Temanggung. Buletin Tanaman Tembakau, Serat dan Minyak Industri.(2) 45-59.

Pranoto, E.N., Widodo, F.M., dan P. Delianis. 2012. Kajian aktivitas bioaktif ekstrak teripang pasir (Holothuria scabra) terhadap jamur Candida albicans. Jurnal Pengolahan dan Bioteknologi Hasil Perikanan. 1(1): 1-8.

Putri, W. S., Waeditini, N. K., Larasanty, L. P. F. 2013. Skrining fitokimia ekstrak etil asetat kulit buah manggis (Garcinia mangostana L.). Skripsi. Jurusan Farmasi FMIPA Universitas Udayana. Bali.

Rahma, A. 2013. Analisis Produksi Dan Kandungan Bahan Aktif Kaempferia parviflora Wall.Ex.Baker Pada Ketinggian Dan Tingkat Naungan Yang Berberda. Skripsi Fakultas Pertanian Institut Pertanian Bogor.

Rice, E.L. 1979. Allelopthy $2^{\text {st }}$ ed. Academic Press. New York.

Rizkitavani, D.V,. dan I. P. Kristianti.2013. Studi potensi ekstrak daun ketapang (Terminalia catapa) terhadap gulma rumput teki (Cyperus rotundus). J. Sains dan Seni Pomits, 2(2): 2374-3520.

Tarigan, M. E. P. 2015. Potensi alelopati beberapa tanaman tahunan terhadap pertumbuhan gulma bayam duri (Amaranthus spinosus L.). Skripsi. Jurusan Agroteknologi Fakultas Pertanian. Universitas Syiah Kuala. Banda Aceh.

Unal B.T, A. Guvensen , A.E Dereboylu, dan M. Ozturk. 2013. Variations in the proline and total protein contents in Origanum sipyleum L. from different altitudes of spil mountain, Turkey. Pak J Bot. 45:571-576 